\title{
Jamary Oliveira (1944 - 2020), o professor da pasta preta, pela memória da Coordenaçáo do PPGMUS-UFBA
}

\author{
Diana Santiago da Fonseca \\ (com colaboraçóes de Flavia Candusso, Ana Cristina Tourinho e Joel Barbosa) \\ Universidade Federal da Bahia Orcid: 0000-0002-0780-1797 \\ Universidade Federal da Bahia Orcid: 0000-0002-7409-5378 \\ Universidade Federal da Bahia | ID Lattes: 9544709180409048 \\ Universidade Federal da Bahia | Orcid: 0000-0003-2428-1313
}

O Programa de Pós-Graduação em Música - PPGMUS-UFBA, face à despedida do Prof. Jamary Oliveira vem - através da memória da sua coordenação - prestar um preito de gratidão e reconhecimento pelas inúmeras e imensas contribuiçóes deste eminente professor ao programa e à formação em Música no Brasil.

Quem chegava às 7:30h da manhã no primeiro andar da Escola de Música da UFBA (EMUS-UFBA) na década de 80, já se deparava com Jamary sentado numa das duas largas cadeiras pretas acolchoadas que ficavam no vão do andar, bem em frente à escada, na parede oposta de quem por ali subia. Com sua inseparável pasta 007 pousada no chão, ao seu lado, e prestes a iniciar, às $8 \mathrm{~h}$, uma de suas turmas de Literatura e Estruturação Musical, nessa época em que a tecnologia digital ainda engatinhava, ele esperava a Biblioteca da EMUS-UFBA abrir, para munir-se dos materiais que iria utilizar na aula. Fazia isso sem reclamar, mas não sem deixar de resmungar, inflamado, para quem estava no entorno, quando os bibliotecários eventualmente atrasavam.

As aulas de Literatura e Estruturação Musical, melhor conhecidas até hoje na EMUS -UFBA como aulas de LEM, sempre estiveram no centro dos vários cursos de graduação da Escola, e os compositores do corpo docente sempre tiveram as turmas da disciplina sob sua condução. Quem foi aluno de Jamary nesse âmbito, estava sob a tutela de um professor dedicado, minucioso e direto; tão direto, sistemático e sincero, que chegava ao ponto de avisar ao eventual estudante culpado de falta de frequência - que mal se sentara, não fizera nenhuma pergunta e tentava mesmo evitar o assunto - a reprovação por falta à qual já estava sujeito. Esse fato ocorria com maior solenidade, em alto e bom som, no exato ponto do calendário em que ele ou ela (que haviam sido devidamente alertados quanto às normas da UFBA no início do curso) atingisse o limite percentual de faltas regulamentado, e isso, com as precisas somas percentuais da ocorrência! 


\begin{abstract}
"Quando ingressei na Escola de Música da UFBA em 1976, já possuía um diploma de nível superior em música da Universidade Católica do Salvador, mas mesmo assim preferi fazer um novo vestibular. No meu primeiro ano Jamary estava indo para o doutorado em Austin. Mas ele avisou aos novatos que ingressavam, 'vocês serão meus alunos quando eu retornar'. E assim foi, Jamary foi meu professor em LEM IV. Nunca estudei tanto em toda minha vida. Me recordo de haver ficado para a prova final e escutar infinitamente

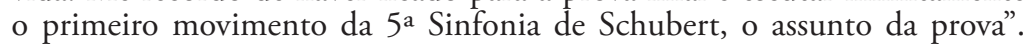
(Cristina Tourinho)
\end{abstract}

Era com essa mesma precisão que conduzia suas aulas, explicando termos e conceitos, corrigindo os exercícios por ele determinados, indicando o repertório de peças a serem conhecidas e reconhecidas auditivamente nas várias avaliaçóes ao longo do ano, assinalando num relâmpago todas as paralelas, condenadas por Fux, escondidas nos exercícios apresentados, respondendo sucinta e precisamente às perguntas formuladas, sempre aberto às dúvidas e ao diálogo.

Jamary era uma pessoa simples. Ao retornar do seu doutorado em Austin, Texas, ele voltava um pouco mais velho e ainda mais sábio, porém, sempre acessível aos estudantes e colegas. A diferença mais perceptível, no trato diário, foi a substituição da 007 por uma pasta de couro, que passou a envelhecer a seu lado, agora carregando não apenas composiçóes, exercícios, vários livros e os documentos burocráticos inevitáveis ao docente universitário, mas também os equipamentos que a tecnologia proporcionava a cada momento..

Jamary era o acadêmico das definiçóes cortantes. Talvez devido a seu falar sintético, suas frases tinham efeito duradouro. Você as ouvia e elas se lhes acometiam, por assim dizer. Você ficava inflamado por elas e as sofria. Como aquela que, burlando a revolta incrédula dos intérpretes presentes, afirmava categoricamente, em plena aula: uma composição, depois de escrita, não precisa mais sair da gaveta em que for colocada!

Ele era preciso e pontual em suas observaçóes. Um dia, lendo um livro em francês com um dicionário do lado, ele me perguntou porque usava um dicionário e respondi que era para consultar as palavras que não sabia. Ele perguntou se eu sabia o significado de todas as palavras quando lia em português e falei que não. Nunca mais li algo em francês com um dicionário...!

Não apenas no ensino - na graduação tanto quanto na pós - Jamary era direto e pontual. Membro fundador do Programa de Pós-Graduação em Música da UFBA, que nasceu "Mestrado em Música" em 1990, sua participação no Colegiado do Curso ocorreu como decorrência inevitável de seu percurso na EMUS-UFBA. Conduzido pelo seu colega mais velho e amigo, o Prof. Dr. Manuel Veiga, que o estimulou a realizar sua pós-graduação no exterior, a ele sucedeu na coordenação do PPGMUS. Ali, equilibrava-o na balança intelectual. De fato, estavam acostumados a trabalhar em conjunto desde a década de 1960, quando, na Reforma Universitária, entre 1968-1971, coordenaram a elaboração do currículo dos Cursos de Graduação em Música da Escola que foi, nesta época, batizada como "de Música e Artes Cênicas”. Os dois sempre foram antíteses que se entendiam, em admiração mútua, a despeito dos quilômetros de distância entre prolixidade e quase silêncio, e das intempéries deles decorrentes.

Enquanto coordenador do Colegiado, sua atuação foi, como se diz hoje, transparente, secundado pela fiel escudeira, Sra. Anorita Guimarães, a secretária das primeiras gestóes do Programa. Nele, com sua capacidade de agregar, envolveu seus orientandos na criação do ICTUS em 1999, um dos periódicos acadêmicos pioneiros na área. 
Jamary era figura marcante nos Seminários do PPGMUS-UFBA, que naquele período aconteciam em fluxo contínuo ao longo do ano e requeriam presença obrigatória para docentes e discentes. Era ele levantar a mão para algum comentário, e já se esperava alguma surpresa, tensão dominante que, breve, se resolvia em riso geral ou réplica acalorada.

Soube deixar discípulos compositores que o admiram intensamente, a despeito do escorrer dos anos, náo importa desde quando deixaram de ser seus alunos. Com os estudantes de outras áreas da música, a seu turno, soube partilhar generosamente os conhecimentos de teoria, análise e tecnologia musical.

Na pesquisa, além da formação de vários pesquisadores e doutores, podemos destacar que recebeu, em 1991, a maior distinção da UFBA, o Prêmio de "Pesquisador do Ano"; atuou no Research Committee da International Society for Music Education - ISME, e mereceu o carimbo de imortal da Academia Brasileira de Música.

Como gestor acadêmico, além da atuação já mencionada no PPGMUS, foi ViceCoordenador de Ensino dos entâo Seminários de Música da UFBA (1967-1969, enquanto o Prof. Veiga era o coordenador); Coordenador do Curso de Especialização em Música "Teoria Musical", que deu início à Pós-Graduação Lato Sensu em Música na UFBA em 1980; Assessor de Pesquisa e Pós-graduação na Reitoria. Fora da UFBA, atuou ainda como Representante da Área de Artes no CNPq e Presidente da ANPPOM.

Junto a sua alma gêmea, a Dra. Alda Oliveira, construíram uma família admirável e uma geração de discípulos competentes e dedicados, aos quais transmitiram não apenas o cardápio acadêmico de cada uma de suas distintas áreas de atuação, mas, sem muito falar e apontando os caminhos, as habilidades emocionais e administrativas capazes de thes conferir as serenidade e lucidez necessárias para os percursos do ensino e da pesquisa na Universidade.

Chegando hoje ao primeiro andar da EMUS-UFBA, cujo vão foi abolido para dar mais espaço à biblioteca, retorna, à lembrança de quem o conheceu, o professor da pasta preta. Dela, ele sempre soube tirar, como de um tesouro, "coisas novas e velhas": uma partitura de Henry Cowell, para deleite de alguma pianista iniciante querendo conversar com os ventos; um rabisco de série dodecafônica a ser apresentado à turma de LEM do próximo horário (e transformado em seguida em algum exercício); ou uma recém composta Piano piece... Eram sempre inesperadas, as surpresas. E imperecíveis. Em suas formas diversas, plenas de energia, essas lembranças nos fazem esquecer que ele se foi, pois continua conosco, ressoando em nossos coraçôes. Por isso, é tempo de calar e apenas dizer:

Axé, Jamary! Godspeed! 